\title{
Peningkatan derajat obstruksi saluran nafas menurunkan kualitas hidup penderita asma
}

\author{
Marcellino Satriaman Harrio Pujo ${ }^{1}$, Kartini
}

\begin{abstract}
ABSTRAK
\section{LATAR BELAKANG}

Kualitas hidup penderita asma merupakan perasaan seorang penderita asma dalam hidup yang meliputi kenyamanan, keamanan, kemandirian, dan kepuasan dalam hidup. Kualitas hidup pada penderita asma dipengaruhi oleh banyak faktor, antara lain status gizi, tingkat kontrol asma, kepatuhan berobat dan derajat obstruksi saluran napas. Penelitian ini bertujuan mengetahui hubungan derajat obstruksi saluran napas dan karakteristik penderita asma dengan kualitas hidup penderita asma.
\end{abstract}

\section{METODE}

Penelitian ini merupakan studi analitik observasional dengan pendekatan cross sectional yang mengikutsertakan 37 penderita asma yang datang ke RSAL Dr Mintoharjo, Jakarta Pusat. Data dikumpulkan dengan cara wawancara menggunakan kuesioner AQLQ dan pengukuran spirometri yang didampingi oleh dokter spesialis paru. Analisis data menggunakan Uji Fisher Exact dengan tingkat kemaknaan $\mathrm{p}<0.05$.

\section{HASIL}

Hasil penelitian dari 37 responden didapatkan bahwa usia lansia adalah yang terbanyak (64.9\%), lama menderita asma lebih dari 10 tahun sebanyak $32.4 \%$, derajat obstruksi saluran napas berat sebanyak $51.4 \%$ dan penderita asma yang kualitas hidupnya terganggu sebanyak 86.5\%. Usia, lama menderita asma, dan derajat obstruksi saluran napas berhubungan dengan kualitas hidup penderita asma $(\mathrm{p}<0.05)$, tetapi jenis kelamin tidak berhubungan dengan kualitas hidup penderita asma $(\mathrm{p}>0.05)$.

\section{KESIMPULAN}

Derajat obstruksi saluran nafas berhubungan dengan kualitas hidup seorang penderita asma. Semakin berat derajat obstruksi saluran nafas, semakin berat gejala yang ditimbulkannya sehingga menurunkan kualitas hidup.

Kata kunci : obstruksi saluran napas, kualitas hidup, penderita asma
${ }^{1}$ Program Studi Kedokteran, Fakultas Kedokteran Universitas Trisakti, Indonesia

${ }^{2}$ Departemen Histologi, Fakultas Kedokteran Universitas Trisakti, Indonesia

\section{Korespondensi: \\ Kartini \\ Departemen Histologi, Fakultas \\ Kedokteran Universitas Trisakti, \\ Indonesia, Jalan Kyai Tapa No. 260, Grogol, Jakarta Barat \\ Email: kartiniedwin@trisakti.ac.id}

J Biomedika Kesehat 2019;2(3):99-103 DOI: 10.18051/JBiomedKes.2019. v2.99-103

pISSN: 2621-539X / eISSN: 2621-5470

Artikel akses terbuka (open access) ini didistribusikan di bawah lisensi Creative Commons Attribution 4.0 International (CC-BY 4.0) 


\section{ABSTRACT}

\section{Increasing the degree of airway obstruction reduces the quality of life in asthma patients}

\section{BACKGROUND}

Quality of life asthma sufferer is a person's feelings of asthma in life which includes comfort, safety, independence, and satisfaction in life. Quality of life in people with asthma is influenced by many factors, including nutritional status, asthma control, medication adherence and degree of airway obstruction. This study aims to determine the relationship between degree of airway obstruction and quality of life asthma sufferers.

\section{METHODS}

The study was an observational analytic with a cross-sectional approach which included 37 asthmatics who came to RSAL Dr. Mintoharjo, Central Jakarta. Data were collected by interview using the AQLQ questionnaire and spirometry measurements accompanied by pulmonologist. Data analysis using Fisher Exact test with a significance level of $\mathrm{p}<0.05$.

\section{RESULT}

The results of the 37 respondents found that the age of the elderly was the most $(64.9 \%)$, the duration of asthma more than 10 years as much as $32.4 \%$, the degree of severe airway obstruction as much as $51.4 \%$ and asthma sufferers whose quality of life was disturbed as much as $86.5 \%$. Bivariate analysis showed a significant relationship between age, duration of asthma, and the degree of airway obstruction with quality of life of asthmatics $(p<0.05)$. While gender had not related to the quality of life of people with asthma $(p>0.05)$.

\section{CONCLUSION}

Increasing the degree of airway obstruction reduces the quality of life in asthma patients.

Keywords : airway obstruction, quality of life, asthma sufferers

\section{PENDAHULUAN}

Kualitas hidup secara umum sangat beragam dari berbagai pakar dan tidak konsisten. (1) Secara umum kualitas hidup adalah perasaan dan pernyataan rasa puas seseorang individu akan kehidupannya secara menyeluruh (menjalani hidup dengan nyaman, jauh dari ancaman dan terpenuhi kebutuhan dasarnya).(2) Hal ini diperjelas juga karena belum ada konsensus yang menetapkan definisi dari kualitas hidup yang dipengaruhi oleh kesehatan. Kualitas hidup menurut mereka yang berpikir dengan penekanan holistik adalah kesejahteraan sosial, emosional, dan fisik setelah mendapatkan perawatan hingga mendapatkan dampak kesehatan seseorang mampu untuk menjalani kehidupan yang memuaskan. ${ }^{(3)}$ Kualitas hidup terkait kesehatan merupakan pengalaman subjektif pasien terhadap penyakitnya dan kepuasan hidupnya. ${ }^{(4)}$ Kualitas hidup penderita asma merupakan kualitas hidup seseorang yang dipengaruhi oleh asma dan mempengaruhi faktor psikososial dan keleluasaan penderita asma dalam melakukan aktivitas. Dari hasil survei respresentatif kualitas hidup penderita asma pada dewasa ditetapkan prevalensi pada $12 \%$ populasi. $(5,6)$

Identifikasi dan memperbaiki gangguan kualitas hidup merupakan komponen penting pada penatalaksanaan asma. Perhimpunan Dokter
Paru Indonesia menetapkan bahwa tujuan utama penatalaksanaan asma adalah meningkatkan dan mempertahankan kualitas hidup agar dapat hidup normal tanpa hambatan dalam melakukan aktivitas sehari-hari. ${ }^{(7-8)}$ Pada umumnya kualitas hidup penderita asma akan lebih buruk dibandingkan dengan orang yang tidak menderita asma. ${ }^{(5)}$ Kualitas hidup penderita asma dipengaruhi oleh berbagai hal, antara lain sosiodemografi seperti: jenis kelamin, lama menderita asma, usia dan kepadatan rumah. Selain itu, faktor lain yang mempengaruhi, yaitu: status gizi, kepatuhan meminum berobat, tingkat kontrol asma, dan derajat obstruksi saluran napas yang biasa dinilai dengan nilai fungsi paru. ${ }^{(8-10)}$ Penelitian sebelumnya menyatakan terdapat hubungan antara kualitas hidup penderita asma dengan nilai fungsi paru $(\mathrm{p}=0.02){ }^{(5)}$ Hasil penelitian lain menyatakan bahwa derajat asma mempengaruhi kualitas hidup penderita asma. ${ }^{(11)}$ Namun berbeda dengan penelitian yang menyimpulkan tidak ada hubungan antara obstruksi saluran napas dengan kualitas hidup penderita asma. Menurut penelitian ini tingkat obstruksi saluran napas yang ringan justru memiliki skor kualitas hidup seperti orang normal/tanpa gangguan, sedangkan pada obstruksi saluran napas sedang justru kualitas hidupnya terganggu. ${ }^{(12)}$

Riset Kesehatan Dasar tahun 2007 
mencatat bahwa prevalensi asma adalah sebesar 3.5\%. ${ }^{(13)}$ Data riset pada tahun 2025 diperkirakan ada 400 juta penderita asma, dan kurang lebih 250.000 orang meninggal tiap tahunnya karena asma. Asma memiliki dampak negatif pada kualitas hidup, gangguan asma menyebabkan aktivitas sehari-hari penderitanya terbatas. Hal tersebut dapat mempengaruhi produktivitasnya sehingga bisa tidak masuk sekolah maupun bekerja yang dapat berdampak pada pendidikan dan karirnya. $(14,15)$ Penelitian ini bertujuan menilai hubungan derajat obstruksi saluran napas dan kualitas hidup penderita asma dan diharapkan hasil penelitian ini dapat menjadi dasar bagi tata laksana asma yang baik sehingga dapat meningkatkan kualitas hidup penderita asma.

\section{METODE}

Penelitian ini merupakan studi observasional analitik dengan pendekatan cross sectional (potong silang). Penelitian dilaksanakan mulai November 2018 hingga Januari 2019 berlokasi di Poliklinik Paru RSAL dr. Mintoharjo, Jakarta Pusat. Subjek penelitian dipilih dengan memperhatikan kriteria inklusi, yaitu penderita asma berusia 12-65 tahun; dan kriteria eksklusi, yaitu penderita paru lain selain asma dan gizi buruk. Responden yang memenuhi kriteria inklusi diberikan penjelasan mengenai penelitian ini dan bila menyetujui perlu menandatangani inform consent. Sebanyak 37 subjek dipilih dengan menggunakan tehnik non randomconsecutive sampling. Pengambilan data kualitas hidup menggunakan Ashtma Quality of Life Questionnaire (AQLQ) dan pengambilan data derajat obstruksi salura napas dengan spirometri yang hasilnya dianalisis oleh dokter spesialis paru. Analisis statistik untuk menilai hubungan derajat obstruksi saluran napas, usia, lama menderita asma dan jenis kelamin dengan kualitas hidup penderita asma menggunakan uji Fisher dengan tingkat kemaknaan $\mathrm{p}<0.05$. Penelitian ini telah mendapat persetujuan Komite Etik Fakultas Kedokteran Universitas Trisakti dengan No.10/ KER-FK/VIII/2018.

\section{HASIL}

Berdasarkan hasil analisis univariat diperoleh data sebagai berikut: responden berjenis kelamin laki-laki (59.45\%) lebih banyak dibandingkan perempuan; variabel usia didominasi oleh kategori lansia (64.9\%), sebanyak 32.4\% responden menderita asma lebih dari 10 tahun; dan sebanyak 51.4\% responden mengalami obstruksi saluran nafas yang berat. Variabel kualitas hidup didapatkan sebanyak $86.5 \%$ responden mengalami kualitas hidup yang terganggu (Tabel 1).

Tabel 1. Frekuensi distribusi berbagai variabel

\begin{tabular}{lcc}
\hline Variabel & $\begin{array}{c}\text { Jumlah } \\
(\mathbf{n}=\mathbf{3 7})\end{array}$ & $\begin{array}{c}\text { Presentase } \\
\mathbf{( \% )}\end{array}$ \\
\hline Jenis Kelamin & & \\
$\quad$ Perempuan & 15 & 40.55 \\
$\quad$ Laki-Laki & 22 & 59.45 \\
Usia & & \\
$\quad$ Remaja - dewasa & 13 & 35.1 \\
$\quad$ Lansia & 24 & 64.9 \\
Lama Menderita & & \\
Asma & & \\
$\quad>0-\leq 2$ tahun & 6 & 16.25 \\
$\quad>2-\leq 6$ tahun & 10 & 27.0 \\
$\quad>6-\leq 10$ tahun & 9 & 24.35 \\
$\quad>10$ tahun & 12 & 32.4 \\
$\begin{array}{l}\text { Derajat obstruksi } \\
\text { saluran napas }\end{array}$ & & \\
$\quad$ Obstruksi ringan & 18 & 48.6 \\
$\quad$ Sedang & 19 & 51.4 \\
Obstruksi berat & 19 & \\
Kualitas hidup \\
penderita asma & & \\
$\quad$ Tidak terganggu & 5 & 13.5 \\
$\quad$ Terganggu & 32 & 86.5 \\
\hline
\end{tabular}

Keterangan: $n=$ jumlah subjek (sampel)

Penderita asma dengan derajat obstruksi berat paling banyak mengalami kualitas hidup yang terganggu (51.4\%). Responden yang menderita asma dengan onset lebih dari 10 tahun paling banyak mengalami kualitas hidup yang terganggu (32.45\%). Penderita asma berusia lansia paling banyak mengalami kualitas hidup terganggu (64.9\%).

Hubungan variabel bebas dan variabel tergantung antara derajat obstruksi saluran nafas, lama menderita asma, usia dan jenis kelamin dengan kualitas hidup penderita asma disajikan pada Tabel 2.

Derajat obstruksi saluran napas berhubungan dengan kualitas hidup penderita asma ( $\mathrm{p}=0.02)$, demikian juga usia berhubungan dengan kualitas hidup penderita asma $(\mathrm{p}=0.003)$, sedangkan jenis kelamin tidak berhubungan dengan kualitas hidup penderita asma $(\mathrm{p}=1.000)$. Untuk menilai hubungan lama menderita asma dan kualitas hidupnya menggunakan uji Likelihood ratio dan didapatkan hasil tidak ada hubungan kedua variabel tersebut $(\mathrm{p}=0.024)$. 


\section{PEMBAHASAN}

Hasil penelitian pada variabel derajat obstruksi saluran napas dan kualitas hidup dapat disimpulkan bahwa terdapat hubungan obstruksi saluran napas dengan kualitas hidup penderita asma.

Hasil ini sesuai dengan penelitian yang menyimpulkan adanya hubungan antara derajat obstruksi saluran napas dan kualitas hidup penderita asma dengan $\mathrm{p}=0,01 .{ }^{(16)}$ Penelitian memperlihatkan korelasi yang lemah antara derajat obstruksi saluran napas dan kualitas hidup penderita asma. ${ }^{(5)}$ Hal tersebut dapat terjadi kemungkinan dikarenakan derajat obstruksi saluran napas dan derajat asma bersinergis dalam mempengaruhi domain gejala pada kuesioner $A Q L Q$. Hasil ini berbeda dengan penelitian yang menyimpulkan tidak ada hubungan antara obstruksi saluran napas dan kualitas hidup penderita asma. Dinyatakan pula bahwa kisaran nilai kualitas hidup antara penderita asma dengan obstruksi ringan dan sedang sangat jauh bedanya. Tingkat obstruksi saluran napas yang ringan justru memiliki skor kualitas hidup seperti orang normal atau tanpa gangguan, sedangkan pada obstruksi saluran napas sedang justru kualitas hidupnya terganggu. ${ }^{(12)}$

Hasil penelitian pada variabel lama menderita asma dan kualitas hidup dapat disimpulkan bahwa terdapat hubungan antara lama menderita asma dan kualitas hidup penderita asma. Hal ini sesuai dengan penelitian yang menyatakan bahwa ada hubungan antara lama menderita penyakit dengan tingkat depresi, dikarenakan ketidaknyamanan, ketidakmampuan, ketergantungan dan ketidakamanan dalam waktu yang lama dapat membuat seseorang cenderung memiliki tingkat depresi yang buruk. ${ }^{(17)}$ Namun penelitian lain lebih banyak yang menyatakan bahwa lama menderita asma tidak berhubungan dengan kualitas hidup penderita asma. Penelitian lain menyatakan bahwa lama anak menderita asma tidak berhubungan bermakna dengan skor kualitas hidupnya (r: $-0.246 ; p$ : 0.121) ${ }^{(9)}$ Selain itu dinyatakan bahwa lama menderita asma tidak mempengaruhi kualitas hidup dengan koefisien korelasi bersifat lemah-sangat lemah dan secara uji statistik tidak berbeda bermakna $(\mathrm{p}>0.05){ }^{(4)}$ Hal ini mungkin terjadi dikarenakan mudahnya mendapatkan fasilitas kesehatan, atau dikarenakan pasien yang telah lama menderita penyakit asma pada umumnya akan terbiasa terhadap penyakit asmanya sehingga penderitanya tidak menganggap dirinya terganggu oleh penyakitnya.

Hasil penelitian pada variabel usia dan kualitas hidup dapat disimpulkan bahwa terdapat hubungan antara usia dengan kualitas hidup penderita asma. Hasil penelitian ini sejalan dengan penelitian yang menyimpulkan bahwa kesehatan fisik, mental, maupun keterbatasan aktivitas pada penderita asma dipengaruhi oleh usia. ${ }^{(18)}$ Pada penelitian ini sebagian besar responden adalah lansia, yang memang mengaku mengalami keterbatasan aktivitas yang mempengaruhi kualitas hidup pada penderita asma.

Namun penelitian lain menyatakan bahwa faktor usia tidak konsisten dalam mempengaruhi kualitas hidup penderita asma. Beberapa kasus

Tabel 2. Hubungan antara derajat obstruksi saluran nafas, lama menderita asma, usia dan jenis kelamin dengan kualitas hidup penderita asma

\begin{tabular}{|c|c|c|c|c|c|}
\hline \multirow[b]{2}{*}{ Variabel } & \multicolumn{4}{|c|}{ Kualitas Hidup Penderita Asma } & \multirow[b]{2}{*}{$\mathbf{p}$} \\
\hline & \multicolumn{2}{|c|}{$\begin{array}{c}\text { Tidak Terganggu } \\
\text { n }\end{array}$} & \multicolumn{2}{|c|}{ Terganggu } & \\
\hline Derajat Obstruksi Saluran Napas & & & & & \multirow{3}{*}{$0.020^{*}$} \\
\hline Obstruksi ringan - sedang & 5 & 13.5 & 13 & 35.1 & \\
\hline Obstruksi Berat & 0 & 0.0 & 19 & 51.4 & \\
\hline Lama Menderita Asma & & & & & \multirow{5}{*}{$0.024^{\#}$} \\
\hline$>0-\leq 2$ tahun & 2 & 15.4 & 4 & 10.8 & \\
\hline$>0-\leq 6$ tahun & 3 & 8.1 & 7 & 18.9 & \\
\hline$>6-\overline{\leq} 10$ tahun & 0 & 0.0 & 9 & 24.35 & \\
\hline$>10$ tahun & 0 & 0.0 & 12 & 32.45 & \\
\hline Usia & & 125 & 8 & & \multirow{3}{*}{$0.003^{*}$} \\
\hline Remaja - dewasa & 5 & 13.5 & 8 & 21.6 & \\
\hline Lansia & 0 & 0.0 & 24 & 64.9 & \\
\hline Jenis Kelamin & 2 & 54 & 13 & 351 & \multirow{2}{*}{$1.000^{*}$} \\
\hline $\begin{array}{l}\text { Perempuan } \\
\text { Laki-laki }\end{array}$ & 3 & 8.1 & 19 & 51.4 & \\
\hline
\end{tabular}

Keterangan: ${ }^{*}$ Fisher test, ${ }^{*}$ Likelihood ratio, $n=$ jumlah subyek (sample), \%=persen, $p=$ tingkat kemaknaan 
lansia memiliki tingkat stress yang lebih rendah dibanding usia muda. ${ }^{(19)}$ Pada penelitian ini lansia yang memiliki kualitas hidup yang sangat terganggu pada domain fungsi emosi justru banyak yang tidak terganggu, hal ini dikarenakan sebagian besar responden lansia berasumsi bahwa apapun yang terjadi selanjutnya adalah kehendak Tuhan.

Hasil penelitian ini memperlihatkan tidak ada hubungan antara jenis kelamin dengan kualitas hidup penderita asma. Hasil penelitian ini sejalan dengan penelitian yang menyatakan bahwa jenis kelamin tidak ada hubungannya dengan penyakit asma. $^{(9,20)}$ Hal tersebut dikarenakan dalam penelitian ini dan penelitian sebelumnya jumlah responden wanita dan pria tidak berjumlah sama sehingga berkurangnya objektivitas dalam menilai hubungan jenis kelamin dan kualitas hidup.

Hasil penelitian ini diharapkan dapat masukan bagi masyarakat khususnya penderita asma bahwa penyakit ini mungkin memang tidak dapat disembuhkan, namun dapat dikontrol supaya obstruksi saluran nafas yang terjadi tidak semakin memberat karena hal ini dapat mempengaruhi kualitas hidupnya.

Keterbatasan dalam penelitian ini antara lain tidak dapat mengontrol kepatuhan pasien dalam berobat. Hal ini kemungkinan mempengaruhi kualitas hidup penderita asma.

\section{KESIMPULAN}

Derajat obstruksi saluran nafas berhubungan dengan kualitas hidup penderita asma. Semakin berat derajat obstruksi saluran nafas, semakin berat gejala yang ditimbulkannya sehingga menurunkan kualitas hidup.

\section{UCAPAN TERIMA KASIH}

Ucapan terima kasih kepada staf di Poliklinik Paru RSAL dr. Mintoharjo, Jakarta Pusat yang telah bersedia membantu pengumpulan data pada penelitian ini.

\section{REFERENSI}

1. Farquhar M. Definition of quality of life : a taxonomy. JAN 1995;22(3):502-8

2. Afiyanti Y. Analisis konsep kualitas hidup. JPI 2010;13(2):84-85

3. Carr AJ, Gibson B, Robinson PG. Is quality of life determined by expectation or experience? BMJ;322. Available from: https://doi.org/10.1136/ bmj.322.7296.1240 Acessed on July 16, 2018
4. STIKes YARSI. Kualitas hidup pada pasien pasc stroke di RSUD Ulin Banjarmasin. Dinamika Kesehatan 2017;8(1):119-20

5. Imelda S, Yunus F, Wiyono WH. Hubungan derajat asma dengan kualitas hidup yang dinilai dengan Ashtma Quality of Life Questionnaire. MKI 2007;57(12):436-45

6. Goldney RD, Ruffin R, Fisher LJ, et al. Asthma symptoms associated with depression and lower quality of life : a population survey. MJA 2003;178:437-47

7. PDPI - Asma pedoman diagnosis dan penatalaksanaan di Indonesia. 2013;7-11

8. Bergeron C, Al-Ramli W, Hamid Q. Remodeling in asthma. Proc Am Thorac Soc. 2009; 6: 301-5. DOI: $10.1513 /$ pats.200808-089RM

9. Suharto S. Faktor-faktor yang berhubungan dengan kualitas hidup anak asma. 2005

10. Kusuma HMSC, Kalim KH, Muid M. Hubungan antara derajat obstruksi saluran nafas srangan akut asma dengan jumlah sel-sel inflamasi darah tepi. Jurnal Kedokteran Brawijaya 2004;20(3):142-5

11. Atmoko W, Faisal HKP, Bobian ET, et al. Prevalensi asma tidak terkontrol dan faktor-faktor yang berhubungan dengan tingkat kontrol asma di poliklinik asma Rumah Sakit Persahabatan, Jakarta. J Respir Indo 2011;31(2): 53-9

12. Moy ML, Israel E, Weiss ST, et al. Clinical predictors health-related quality of life depend on asthma severity. Am J Respir Crlt Care Med 2001; 163:924-29

13. Ilyas $\mathrm{M}$, Yunus F, Wiyono WH. Correlation between asthma control test(ACT) and Spiromety as tool of assessing of controlled asthma. J Respir Indo 2010;30(4): 190-5

14. Supianto MJ, Musawaris RF, Yanti SN. Hubungan derajat asma persisten dan kualitas hidup pasien asma dinilai dengan Asthma Quality Of Life Questionnaire(AQLQ). Jurnal Vokasi Kesehatan 2015;1(3):80-4 Kristianingsih A. Faktor Resiko Dismenore Primer pada SMP Kecamatan Natar Kabupaten Lampung Selatan. 2014

15. Zolnoori M, Zarandi MHF, Moin M, et al. Fuzzy rule-based expexrt system for assessment severity of asthma. J Med Syst 2012;36: 1707-17. DOI 10.1007/s10916-010-9631-8

16. Chaidir R, Septika MS. Hubungan derajat asma dengan kualitas hidup yang dinilai dengan Asthma Quality of Life Questionnaire di ruang Poliklinik Paru RSUD DR. Achmad Mochtar tahun 2014. Bukit Tinggi; 20114

17. Lorensia A, Wahjuningsih, Sungkono EP. Hubungan pengaruh tingkat keparahan asma dengan kualitas hidup dalam memicu timbulnya depresi pada pasien asma kronis. J Ilmiah Sain dan Teknologi 2015;8(2) : 21-30

18. Ford ES, Mannino DM, Homa DM, et al. Selfreported asthma and health-related quality of life : finding from the behavioral risk factor surveillance system. Chest 2003 Jan;123(1):119-27

19. Nishiyama O, Taniguchi H, Kondoh Y, et al. Evaluating health-related quality of life in asthma. Allergology International 2005;54:181-6

20. Sihombing M, Alwo Q, Nainggolan O. Faktorfaktor yang berhubungan dengan penyakit asma pada usia $>10$ tahun di Indonesia (Analisis Data Riskesdas 2007). J Respir Indo 2010;30(2):85-91 